\title{
Ethiopian Christianity: A continuum of African Early Christian polities
}

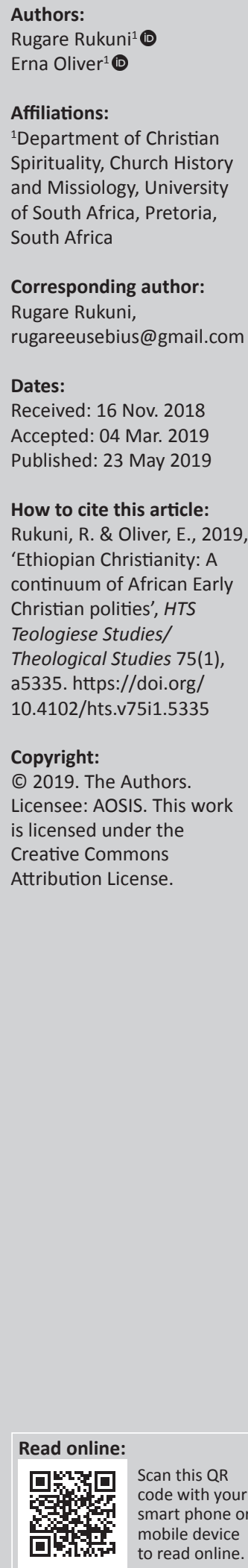

The 4th century CE was definitive for Early Christianity as there emerged an imperial orthodoxy establishment. This was the inception of an era of a Christian polity characterised by symbiotic ties between the imperial establishment and a developing charismatic political Christianity. The established narrative is one overshadowed by the Byzantine influence even in Africa through Alexandria and Carthage. There were, however, dynamics that conceived an African Christian polity, by extension Ethiopian Christianity posed relevance as a complexly diverse Christian political entity. The investigation reviewed 4th-century CE Christianity with regard to the influence of an African Christian polity and, additionally, how it was implied upon relations with the imperial orthodox establishment. Ethiopia became the case in consideration. This was established through descriptive research using document analysis to formulate literature reviews. The development of a Christian political matrix was a dominant feature of Early Christianity, especially after the emergence of a mutual enterprise under imperial orthodoxy. The formative manner of the political characteristic of ecclesiastical leadership was composite to the council resolutions and expansion policy. Inadvertently, the thin line between imperial geopolitical policy and custody of Christendom diminished. Ethiopia intrinsically saw the development of its own Christian political entity, one that curtailed the challenges of ethnic enculturation and schism between charisma and hierarchy. Perceivably, the complexity of the religious political matrix of Ethiopia as derived from its interaction with Byzantine Rome, Alexandria and the Arabian Peninsula was the source for its prolonged existence, thereby establishing basis for further investigation.

Keywords: Church history; Ethiopian Christianity; Byzantine Christianity; Imperial Christianity; Self-definition; Monophysite; Miaphysite.

\section{Introduction: Africa and its political philosophy}

Early Ethiopian Christianity was a composite unit of ecclesiastical and imperial politics. Notably, the prevalence of Ethiopian Christianity is ascribed to the 4th century CE going forward. In view of the emergent Byzantine imperial orthodoxy at the end of this century, an effort will be made to position Ethiopia with respect to the then prevalent contemporary dynamics in Christianity and, more specifically, with regard to the development of a Christian polity that is the political definition of Ethiopian Christianity. In addition, this enquiry is an endeavour to deduce the source for the viability of native Ethiopian Christianity that transcended diverse eras. This will be accomplished through document analysis.

Early African Christianity's political narrative is arguably a juxtaposition of resistance and conformity. As an index reflecting key personalities on different divides of the catholic schism, there were Donatus and Augustine. When reviewed beyond their life spans, these names resembled divergent political ideologies. On one end there is conformity to the imperial establishment and its correspondent catholic orthodoxy in the person of Augustine, while on the other end there is non-conformity to both the imperial establishment and its catholic orthodoxy in the ideology of Donatism. This entrenches the notion of the development of a nationalistic or patriotic orthodoxy in the region of North Africa and possibly its surrounding regions.

The persistent recurrence of the Donatist ideology as a symbol of African intransigence against both the unitate ecclesiae [ecclesiastical unity] and the Pontifex [priest] is definitive of the narrative of African Christianity - Unitate Ecclesiae represented Cyprian's establishment of unified Christianity under the governance of an entrenched episcopal hierarchy (Unit Ec 10-14; Schaff 1885a:744-746); while the Pontifex represented Constantinian sacerdotal actions, which were akin to imperial clerical participation (Orat Const 2.1, 5; Schaff 1885b:884). The narratives of African intransigence can be juxtaposed against elements of sympathy with Rome that 
characterised Augustine. Deductively, it is this counter-play of friend or foe that defined the religious and geopolitical policy of another African Christian Empire. The Kingdom of Ethiopia has a religious narrative characterised by diversity, religious political self-definition and an assertive national autonomy.

\section{Augustine versus Donatus}

In the background to the council of Nicaea, which signalled a solidification of imperial orthodoxy under Constantine, there lurks in the shadows the controversy and schism of the African Church Optatus (Dn 1.11.4; Phillips 1917:23; Leithart 2010:156). The Donatist controversy was defined by intransigent African Christianity's insistence upon a purity from contact with the secular. This materialised in reference to those who had compromised during persecution, whether as traditores surrendering Holy books to the Diocletian persecutors, or as lapsi [fallen] in full compromise as in need of rebaptism (Tilley 2012:289).

The discussion concerning the moral standing and acceptance of fellow believers transcended the ecclesiastical echelons, that is, clergy was no longer exempt from the pure against fallen caste. Given the 2nd- to 3rd-century dynamic of ecclesiastical polities that were an emergent self-definitive element of Christianity, the rigorous approach in the determination of acceptance or non-acceptance of certain believers would spill over into episcopal and clerical claims. Coupled with socio-ethnic dynamics characteristic of Carthage and its historical narrative with Rome, this definitive feature of North African Christianity compositely brewed an episcopal succession dispute (Optatus Dn 1.16-19; Phillips 1917:50-54; Edwards 2006:151).

The Donatist controversy and the corresponding Arles Synod compose the narrative of the emergence of an imperial catholic orthodoxy. As an appendage to the trajectory to Nicaea, the Arles Synod of 314 CE and the Donatist controversy shaped the political self-definition of Early Christianity as imperial polity merged with episcopal polity in the convention of ecumenical councils.

Detachedly, the controversy came to represent a divergent ideology to both the catholic and imperial establishment. It seems the name Donatist transcended its immediate era of influence, finding continuation into Vandal Africa and beyond (Wilhite 2017:219-221). In light of this observation and the dominant voice of Augustine in Christian political thought in the 3rd- to 4 th century $\mathrm{CE}$, deductions regarding Christian political ideologies can be made. Correspondence by Augustine regarding Donatus implies a review of the clash of ideologies in the region and possibly the synthesis of African Christian political philosophy.

After the eminent rise of Donatus and his leadership, a resistance movement against the Catholic establishment, Augustine, an orator and aristocrat by orientation, appealed as the voice of reason. Augustine insisted on Donatus as a disturber of the peace, therefore justifying the exertion of secular authority in quelling the schism (Augustine to Crispin Ep 51.1,3; Atkins \& Dorado 2007:128, 130). Notably, Augustine registered the complaints by the Donatists against the Catholics to have been regarding the authenticity of the baptism administered by catholic clergy who had compromised, additionally, the relationship between the secular authorities and the Catholics (Augustine to Crispin Ep 51.3, 4; Atkins \& Dorado 2007:130, 131).

The conflict regarding the authenticity of baptism administered by catholic clergy and questionable affinity between the catholic clergy and the imperial authorities raises the subject of political identities. To question the right to administer Christian ordinance by the lapsed Catholic clergy was an indirect attack at their ordination (Augustine to Crispin Ep 51.4; Atkins \& Dorado 2007:131). This implied an escalation of episcopal polities stemming from enculturation and selfdefinitive dynamics. The intransigence of African Christianity had been a feature further established during the 2nd- to 3rdcentury persecutions, such as the Decian persecution.

Retrospectively, there had been development of an entrenched stratification among African believers with regard to compromise and non-compromise. Correspondingly, this incited a dual dichotomy between the charismatic and the ordained authority (Tilley 2012:390). The particularity regarding those that had forfeited their moral standing during the persecutions is traceable to orthodox figures in African Christianity as Cyprian On the Lapsed 25 and Epistles 39.3-5, 55 (Schaff 1885a:564, 565).

Donatism as a movement can be understood to have been building on a continuum of North African Christian selfdefinition. The geographical implication of the source of resistance as Carthage can also be argued as having culturalethnic dynamics. The preceding stems from the history of frosty political relations between Rome and Carthage. The Donatist narrative implied a resonance of the Donatist movement with the natives of Carthage, Punic-speaking peoples and other natives who shared resentment against Rome (Roldanus 2006:174).

Augustine's political theology was one that acknowledged the secular powers of Rome, undoubtedly given his aristocratic background, which was the same as that of Cyprian. Augustine, in his epistles, alludes to the concept of patriotism, such as his correspondence with Nectarius where he reflected on responsible citizenship as a virtue (Augustine to Nectarius Ep 90.1; Atkins \& Dorado 2007:1). In addition, his appeal to the proconsul of Africa Apringius on behalf of the Donatists reflected his religious conviction regarding the exercise of secular authority as a divine bestowment (Augustine to Apringius and Marcellinus Ep 133.2; Atkins \& Dorado 2007:62).

The two characters (Augustine and Donatus) and their ideological prominence in the narrative of North African Christianity and its interaction with Rome can deductively be used to formulate some conception regarding the political definition of African Christianity. Inferably, the whole 
conflict regarding ideology may be relegated to what was the prescribed code of reference to Rome (Brown 2000:210). There has been a prior classification of Donatism as a nationalistic phenomenon, thereby limiting it to a movement driven by a form of territorial consciousness. According to the aforementioned view, Donatism thrived mainly on appealing to natives' sense of autonomy from Rome. The theory in discussion has been proven faulty; however, there is a substantial argument for social-cultural dynamics as already established (Wilhite 2017:219-221). The conception developed in the study was not conclusive given an evasion of Tertullian in the preceding review; however, the aim was to deduce a Christian-political model of reference with regard to other regions on the African continent, in particular Ethiopia.

\section{Ethiopia: Assertive Christian autonomy}

The Kingdom of Ethiopia was characterised by a narrative of a developing imperial polity. Significantly relevant to the investigation is the intertwined nature of the religiouspolitical imperial policy. The Constantinian turn and its corresponding ecclesiastical political dynamics can be an implied model. As an additional feature, it seems there was an outgrowth of a more nationalistic sentiment with the development of Ethiopian orthodoxy. From Aezanas to Kaleb, geopolitical policy was enshrined within the connotation of the nation's Christian status. From Greek gold coin inscriptions to an offensive geopolitical policy in support of Christian interest, the Negus(es) [rulers] of Ethiopia were overtly promoting Christianity in a Constantinian style.

\section{Christian authority}

When placed under review, there seems to be relatively insignificant singularity with Ethiopian imperial practice when in consideration of contemporary comparisons. This assumption of an imperial continuum that reflected the imitation imperii [imperial imitation] status quo was a similar practice in Africa by the Hasding Vandal dynasty (Whelan 2018:15). The assumption derives on the presumed influence of Rome or Byzantine upon the respective African regions, hence the native rulers in an autonomous assertion of authority would posture a form of Roman imperial decorum.

Coinage minted during and post Ezana's reign had an emphasised feature of Greek denominational inscriptions (Phillipson 2012:188). The vaguely known MHDYS used Ge'ez, however, though in an impressionably Byzantine manner to affirm his Christian reign as divinely derived. In an overtly Constantinian fashion, the Emperor MHDYS claimed an in hoc signo vinces that is victory through the cross (Phillipson 2012:189). There is also strong affinity between the coin and Theodosius II's 422 CE solidus issue (Phillipson 2012:189). Coinage is archaeological evidence for imperial reign, more specifically for gold coins; however, notably the depictions or inscriptions on these coins reflect aspects of a ruler's reign.

The Ethiopian emperors notably announced the extent of their domain through coinage inscription. A fluid claim they made regarding their geopolitical influence was their authority over the Arabian Peninsula, as they were titled king of Himyar (Phillipson 2012). This accumulatively explains their autonomous geopolitical domination. That such a self-conscious monarchy defined by nationalistic sentiment could use the foreign Greek language or appeal to Byzantine coin culture implies upon the geopolitical policy of the empire.

The use of Greek, the language of Byzantine Rome's Christian domain, implies contact between the two empires. The use of Greek on coinage that was money, an economic means in trade, implies mercantile connections between Byzantium and Ethiopia. The preceding facts are not unusual conclusions against the weight of evidence, by extension the use of Greek and impersonation of Byzantine imperial culture as implications. The narrative of 4th- to 5th-century Christianity lies within the connotations of a continuum of Constantinian imperial Christian policy. This in the minimum argues for a subservient Ethiopian Christianity. The deduction made is outside Byzantine and Rome; Ethiopian Christianity was of marginal influence.

\section{Ethiopia and religious controversy}

There is apparent inevitability of a contact theory between Byzantine Christianity and Ethiopian Christianity. The Greek inscriptions and evidenced impressionism imply an appreciation of the established imperial Constantinian orthodoxy; however, to conclude a subject or client Ethiopian Christianity is unsubstantiated. Given the domain of Rome and the re-conquest of Africa from the Vandals by the Byzantine emperors, Alexandria and partially Carthage remained somewhat under Roman control (Wilhite 2017:293). This meant by extension Ethiopian Christianity would be controlled through the Alexandrian connection.

The narrative regarding the establishment of Ethiopian Christianity shows the prominence of the influential Alexandrian see over the affairs of Africa. The appointment of Frumentius was at the discretion of the Episcopate of Alexandria (Theodoret Hist. Ec 1.22, Schaff 1885c:127). There is a narrative of divergent interaction, however, with regard to the imperial eastern Nicene orthodoxy. The 4th century had seen the development of a conciliar dynamic under Constantine, which brought with it an orthodoxy establishment. The Arian controversy and the corresponding Nicene council had incited a trajectory of conciliar polities that entangled the ecclesiastical imperial establishment (Barnes 2011:141).

The Christendom implicatively became a domain for the exertion of imperial policy, hence the Christian imperial establishment would also extend the empire through religious policy, it would appear. The rise and demise of the Hasding Vandal dynasty in North Africa shows that conquest was not relegated to political-regional control alone. The swing in fortunes for both Nicene and Homoian aligned clergy as a factor of political dynamics implies an attempt by either 
mornachies to have had an ecclesiastical connection in their governance of the empire (Victor HP 1.43-44, 1.48, Moorhead 1992:18-21) (Fulgentius V. Fulg.6-7, 21, Eno 1997:16-21, 40-43). This poses a dynamic feature regarding the discussion at hand given the geographical positioning of Ethiopia and Roman or Byzantine territorial and military policy.

Ethiopia is asserted as having been independent from Roman imperial domination. Ethiopia was a regional influence as noted in the coinage inscriptions of the Negus [ruler]. Sovereign claims regarding the Arabian Peninsula, for example, and the Negus [ruler] as king of kings imply an actively offensive territorial policy (Bowersock 2013:68). Deductively, this correspondingly implies that Byzantine imperial policy regarding geopolitical ties with Ethiopia was to be at a level of mutuality. There was no inferior ally despite the apparent superiority of Byzantine. The geopolitical cooperation of the two empires regionally was some form of justification to this reality (Procopius Wars I.19-20; Dewing 1914-1928:1:178-195). Observably, however, Byzantium attempted to control the Ethiopian Christian establishment by the Alexandrian connection it would seem.

\section{Positioning Ethiopia in the Nicene and Chalcedonian polities}

The actions of the Emperor Constantine with regard to Nicaea had seen the consummation of a process of conciliarecclesiastical polities in the establishment of orthodoxy. The trajectory incited by the ecumenical councils was definitive to Christianity post the reign of Constantine. As the orthodox heretical caste recurred, so also did the episcopate gain more political eminence. The episcopal polities connected with imperial policy were perceivably another arm of government. This can be evidenced by quasi-judicial powers of the bishops as per the grants of Constantine (Hist Ec 7.30.7, Maier 2007:247). The efficiency of this connection is inferred in the narrative of ecclesiastical history. Given the autonomy of the Ethiopian empire and its development as a religious political entity, the ecclesiastical imperial ties would imply the emergence of a nationalistic orthodoxy.

In positioning Ethiopian Christianity in the 4th century CE, going forward, certain establishments have to be made in order to deduce the trajectory of a native orthodoxy:

1. The first element is the religiosity of the emperors, a basis for their involvement in these definitive political-religious international debates.

2. The second being the Ethiopian reaction to the postNicene entrenchments of the Arian and Nicene parties.

3. Lastly, a positioning of the Ethiopian response to the Chalcedonian resolution on Monophysitism versus Miaphysistism.

\section{Imperial religiosity and the ecclesiastical establishment}

Constantine ushered an era of explicit Christian imperial policy where the emperor would emphasise his beliefs in his economic and military policy. Praise and tribute, credit that had all along been due to pagan gods, was now to be assigned to the monotheistic Christian God (Kee 2017:24). The same transition took place with the Ethiopian dynasties it would seem. From attributing dominion to Mahrem (RIE 186, Phillipson 2012:95), the negus Aezana [king] in international Greek inscriptions declared himself a doulos Christi [slave of Christ], a title attributable to Pauline writings (Rm 1:1; Bowersock 2013:73). There, however, is some ambiguity attached to the differences between the Greek inscriptions of Aezana and the Ethiopic or Ge'ez ones. Phillipson (2012:97) and Bowersock (2013:73) infer, based on the inscription that was more explicitly detailed in the Greek, that this may be an indication of local resistance to the new faith by the native population. Hence, the emperor would be more openly Christian to the foreign world, rather maintaining native religious dynamics. This argument when compositely considered along the use of Ge'ez by MYDHS can also imply another conclusion.

The emperor or Negus was possibly asserting his relevance as a Christian ruler, one in control of another domain, one without Roman or Byzantine reach. The cooperation between Byzantine and Ethiopia to entrench Christian presence in Arabia implies common interest of Christian allies. The king's role in ecclesiastical matters was effected through the clergy, this being characterised by monastic dynamics.

The prominence of the nine Syrian monks in the religious narrative regarding Nestorianism evidences the centrality of the clergy in establishing an Ethiopian version of Christianity to parallel the Byzantine imperial orthodoxy establishment (Friedlander \& Fredlander 2015:14). The Ethiopian Synaxarium was a translated and transformed form of the Coptic Synaxarium (Liturgical Collection of Saints' lives) to reflect a Ge'ez or native Monophysite faith rather than a Greek or foreign Miaphysite orthodoxy (Friedlander \& Fredlander 2015:15).

The actions of the monks were apparently at the largesse of the Negus; this can be implied given the very narrative of the origins of Christianity in Ethiopia. There narrative regarding Frumentius and Negus Aezana reads as a romance between ecclesiastical episcopal polities and Ethiopian imperial religious policy (Rufinus, Historia Ecclesiastica 10.9-10; Amidon 1997:18-20). Given the international nature of Christianity and the influence of Byzantine imperial policy over the conciliar form of orthodoxy and extendedly a somewhat captured episcopate, the narrative also shows how from the very inception of Christianity in Ethiopia there would be international or regional geopolitical implications.

The eminence of monastics in Ethiopian Christian selfdefinition cannot be understated, this inferably a function of the extended Alexandrian influence.

\section{Ethiopia and Nicene polities}

Christianity in the 4th century had been introduced to the definitive dynamic of imperial polities and an ecumenically 
determined orthodoxy at the council of Nicaea (cf. Behr 2004). The dynamic regarding episcopal polities redefined Christianity at this juncture as it had received a boost from the emperor (cf. Van Dam 2012). The rifts emergent from the controversies precipitating the councils entrenched a caste that transcended geography and time. The Donatists, Arians or Homoians might have been incriminated as heretics or divergent from orthodoxy; however, the creeds for their disapproval did not entail the demise of their movements. The fact that these divergent positions with regard to Christian orthodoxy were held by influential clerics implied their political nature.

The involvement of Athanasius, the See of Alexandria, in the establishment of Ethiopian Christianity through the ordination and possibly mentoring of Frumentius conceives the basis for this respective discussion. Athanasius stands out distinctly with regard to the $325 \mathrm{CE}$ Nicene Council as belonging to the orthodox anti-Arian party Athanasius (Hist Arian 1; Schaff 1885d:526). In addition, Athanasius remained obstinately anti-Arian, an unfortunate position with the rise of pro-Arian emperor Constantius II. The implicated nature of Ethiopian Christianity was then reflected as a factor of Byzantine imperial Christendom after the emperor recalled Athanasius so as to appoint George of Cappadocia, who, in turn, was also mandated to re-examine the Athanasius appointed Frumentius (Athanasius. Apol.29, 31; 1885d:495, 497-498).

The Ethiopian response to the Byzantine exercise of authority over Christendom is another matter. The apparent reality regarding Athanasius that builds the narrative of the political definitive nature of Ethiopian Christianity is a review of the ascetic establishment and correspondent ecclesiastical polities. Against the backdrop of a recurrent clash in African Christianity between the charismatic and established authority, Athanasius, as Bishop of Alexandria, managed to forge a union between the two. Athanasius established an alliance between the episcopate and the ascetics of Egypt (Gwynn 2012:120).

The political self-definition of African Christianity was characterised by schisms that stemmed from the competition between the orthodox establishment and charismatic movements. The Donatist controversy and the Meletian schism were a result of perceived compromise by certain clergy during the persecutions and correspondingly this disqualified their claim to holy office (cf. Brent 2009). The influence of the Donatist movement has been highlighted as it epitomised resistance against the foreign orthodox establishment.

Ascetism was intrinsically definitive of the political matrix of Christianity. This was a neutralising dynamic to the emergent episcopal imperial connection, a phenomenon of 4th-century Christianity and its emergent orthodoxy (Rapp 2005:137-152).

Athanasius maintained balance between the ideals of ascetism and the demands of episcopal power. Alexandria was characterised by iconic ascetics such as Anthony, yet the primacy of Athanasius as an episcopate remains factual. Notably, the widening gap between the clerics and monks was entrenched because of the imperial largesse upon the episcopate. This may further imply that Athanasius' balance between holiness and administration was a function of his resistance against the imperial establishment. This corresponds to the narrative of Athanasius' relations with Constantius II and even Constantine before him. Cassian's call for monks to flee from women and bishops (Institutes 11.18; Schaff 1885e:666) gives credence to Athanasius having been central to the possibility of an episcopal-ascetic union. The preceding is possibly because Cassian is writing a generation after Athanasius. The bond between hierarchy and charisma in the Alexandrian church was foundational and definitive of episcopal polities intrinsically (Gwynn 2012:121).

\section{Ethiopia and the monks}

The considered union between episcopal polities and ascetism was a primary feature of Ethiopian Christianity. In line with the deduction of the influence of Athanasius and Alexandria upon the emergent Christianity in Ethiopia, this seems to have been inevitable trajectory. Observably, Ethiopian Christianity would not be of an Alexandrian, Byzantine or Syrian shade but rather a convergence of these influences is traceable in the orthodoxy that became defined as Ethiopian. There is a give and take in the definition of Ethiopian Christianity. There was an apparent assimilation of Alexandrian ascetic practice mutually synced with the adoption of Byzantine imperial practice within the religiouspolitical matrix of Ethiopia. In addition to the precedingly discussed influences was the regional Judaic influence stemming from the Himyaritic environment and the very history of Ethiopian Judaism. Therefore, there is a confluence of religious elements in the build-up to a national orthodoxy.

Unmistakably, the Ethiopian Monasticism and Hagiography is elementary to its Christian legend as evidenced by its documentation in the Kebra Naghast [Glory of kings] tradition, historical sources, ecclesiastical art and the Synaxarium [liturgical collection of saints' lives]. In accordance with the deduction concerning the social-ethnic confluence of religious elements upon Ethiopian Christianity, the saints of Ethiopia reflected an exotic and natively grown orthodoxy. Paramount to the current discussion, however, is the manner in which the monasticism and hagiography of Ethiopia compositely formed the Christian political ideology of their nation. In the minimum, the legends of the Synaxarium [liturgical collection of saints' life] reflect the autonomy of the Ethiopian Church and the assertive role of emperors in the protection and furtherance of a national Christian cause with the help of the Ascetic clergy.

The tasa'tu qiddusat [Nine saints] for starters were integrated into the origin tradition of Ethiopian Christianity as they are documented as having introduced a vitalised monastic and more native confession (Pankhurst 2005:35, 38). Through their agency the nation was entrenched in Monophysitism 
and they made Ge'ez translations of several church works, including the Bible (Isaac 2013:62). Considerably, their Syriac origin had corresponding socio-ethnic implications, although there is emphasis within tradition regarding how they integrated well with native customary practices. This resonates with the Donatist local advantage of integration with the natives as reflective of effective enculturation of Christianity. Given the presumptions made regarding the explicit Greek inscriptions versus the vague Ethiopic ones as inference to local resistance to Christianity, the monasticism of the Nine saints could have been the catalyst that popularised Christianity among the populous. The success would be attributable to their use of charisma, an implied function of asceticism.

In the Synaxarium Likanos or Mataa, one of the tasa'tu qiddusat [Nine saints] who translated the Gospel of Matthew into Ge'ez clashed with the Abuna [Ethiopian Patriarch] over the latter's corrupt practices (Budge 1976:257; Friedlander \& Fredlander 2015:16). He was then relegated by the Emperor to Darraga, later on both the Emperor and the Abuna saw reason and therefore allowed him to pursue his mission in Guna-Guna. After a visit by the Emperor Gabre Maskal, the Church of Beta Maskal was built in his honour; also for his missionary endeavours north of the Marab and Belesa rivers he earned the title Apostle of Eritrea (Friedlander \& Fredlander 2015:16). There are possible deductions from this legend regarding the political definition of Ethiopian Christianity: (1) The ascetics-cleric relationship in Ethiopian Christianity was typical of 4th- and 5th-century ecclesiastical polities. There was a clash between holy charisma and holy hierarchy it would appear; however, it was managed amicably through imperial intervention. Correspondingly, the honours by the Emperor upon the monk imply the well-established role of ascetics in the political economy: (2) The expansion of missions in regions beyond the immediate domain of the empire, such as the Eritrean region, implies a conscious geopolitical superiority. The sovereign claim of the Negus over the imperial regions transcended the political domain, but was impressed upon religion itself. The geopolitical policy of Ethiopia had a compositely religious agenda.

The Ethiopian Christianity's ecclesiastical political establishment in the post-Nicene era was a blend of asceticism and imperial clerical interventions. There seems to have been a symbiotic alliance between these political religious entities. The forging of a nationalistic orthodoxy seems to have been consequent of this three-tier synthesis of ecclesiastical and imperial politics. The unique positioning of Ethiopia as a Monophysite Christian confession was a factor of the respective establishment.

\section{Ethiopia and Monophysite self-definition}

Ethiopian Christianity as established was a confluence of exotic and native religious elements. The preceding discussion regarding the political self-definition as consequent of asceticclerical links reflected Alexandrian and Syrian-Jewish influence. The position taken by Ethiopia with regard to the
Monophysite or Nestorian controversy and the corresponding council of Chalcedonia $451 \mathrm{CE}$ is an index to the cultural and political definition of Ethiopian Christianity.

The Jewishness of Ethiopian Christianity is a notably dominant characteristic, which incites enquiry as to the source of this version of Christianity. In the tradition regarding the origins of Ethiopian monotheism and Christianity, there are several definitive stages. A possible categorisation could be as follows:

1. The introduction of Judaism through Menelik - inception of Judaic faith.

2. The conversion of Aezanas - introduction to Christianity $330 \mathrm{CE}$.

3. The migration of the Syrian-Jewish tasa'tu qiddusat (Nine Saints) - entrenchment of Christianity, ca. 480 CE.

The practice of Syrian monks as Jewish Christians is of significance in the socio-ethnic dynamics of Ethiopian Christianity. The primacy of this dynamic as definitive to Ethiopian Christianity was the role the Syrian monks played in the establishment of oral tradition and translation of literal works (Isaac 2013:38). This in the minimum implies their influence on the language of literature and evidently so the work of the tasa'tu qiddusat furthered the drive for $\mathrm{Ge}^{\prime} \mathrm{ez}$ liturgy. This implied a native trajectory for the Christianity of Ethiopia.

Ethiopia has been taken to be explicitly Monophysite (Bowersock 2013:76). Credence to this characterisation also derives from its Judaic complex. The transition from Judaism, and the influence of the monks, was composite to the geopolitical confluence of culture between Ethiopia and Judaic Himyar, which formed the Ethiopian Judaic religious matrix. The Arabian Peninsula had exposure to Jewish enculturation, this being a factor of Jewish migration. Additionally, prior to the rise of Islam, Judaism had made inroads (Bowersock 2013:4). Hence, the affinity to Judaism implied a reserved monotheism and consequently a reserved theology.

Extricably, there is a possibility that Ethiopia and the Chalcedonian resolution are an inappropriate synthesis.

Isaac (2013:38) argues that to Ethiopia has been wrongly ascribed the labels of Miaphysite and Monophysite because of its aggregately detached position with regard to the Nestorian controversy. To start with, the Ethiopian church was not complicit to the conciliar orthodoxy establishment that effected the Chalcedonian resolution. The church of Ethiopia did not even have representation at the Chalcedonian Council (Isaac 2013:39). Isaac (2013:38,39) infers that Ethiopia received Miaphysites and Monophysite monks and maintained cordial relations with Byzantine.

Ultimately, this implies that Ethiopia's orthodoxy regarding the Chalcedonian resolution to Nestorianism was not a function of Byzantine ecclesiastical polity but rather an 
organic position. The definitive conciliar polities of Nestorianism were not factored in Ethiopian ecclesiastical polity definition.

\section{Christian geopolitical policy}

The orthodoxy of the nation was composite in the imperial geopolitical policy. The Greek inscriptions by Ezana were possibly a positioning of the Ethiopian Church in the network of Byzantine imperial orthodoxy (Bowersock 2013:76). For Bowersock, the Monophysite outlook was definitive in regards to Byzantine relations. The imperial diplomatic policy was attached to the Christian dynamic; meanwhile in neighbouring Himyar (a nation under the sovereign claim of the Negus), similar religious-political definitive dynamics were taking form, entrenching a national Judaism.

The growth of Judaism in claimed Ethiopian imperial territory was signal to a dwindling imperial domain. In the name of Christianity, the Negus had a solemn duty to guard the faith in Arabian Himyar. During ca. 400-510 CE, there was a re-engagement of Ethiopian and Himyarite Christianity (Phillipson 2012:203). The Negus regularised a client Christianity in Himyar, even installing a client king Ma'dikrib Ya'fur (Gajda 2009). The Judaic faction retaliated.

In ca. 522-523, Arabian Judaic resistance under Yusuf As'ar Yath'ar/Dhu Nuwas made an attack on Zafar, killing Ethiopians and destroying the Christian Church. This was followed by subsequent attacks, culminating in the siege and persecution of the Christians of Najran, a city $400 \mathrm{~km}$ North of Zafar (Phillipson 2012:204). The burning of Christians to death and their leader, Harit, incited the intervention of the arbiter of Christendom, that is, the Byzantine empire (Procopius History of the Wars, I 19-20; Dewing 1914-1928:1, 178-195).

The narrative reflects the intertwined geopolitical-religious policy of Ethiopia. The installation of a client king so as to retain control of both the region and the Christianity in Himyar reflects a politically defined Christianity, one that had an ecclesiastical imperial establishment. Notably, Harit, the leader of the Najran Christians, was an Arab chieftain implying the possibility of an ethnic-political Christian hierarchy as with the Circumcellions and the Donatists. The client Christianity established in the Arabian Peninsula was enculturated ethnically it would seem.

Although there was an apparent geopolitical interest on the side of the Byzantines, the ecclesiastical nature of the military response was also explicit. Justin, the Byzantine emperor, established the Byzantine-Axumite consortium through the patriarch of Alexandria (Phillipson 2012:204). The Byzantine emperor's appeal for assistance from Kaleb, the Ethiopian Negus, implied the Byzantine imperial Christianity complex. Persian influence in the region of the Arabian Peninsula necessitated the military endeavour by Byzantine; however, indications imply that the Najran persecution escalated the matter.
The mutual interest by both the Ethiopian and Byzantine empires was apparent. This (Himyar) was after all a territory under Ethiopian influence as claimed by the inscriptions of the Negus. In view of the Monophysite and Miaphysite caste between Ethiopian and Byzantine Christianity, a deduction is here made with regard to the give-and-take policy in Christian-political definition of Ethiopia. There were future complexities that would riddle this combined military endeavour in protection of these Himyaritic heretics.

The imperial orthodox establishment of the Byzantine empire would obviously resent those in non-conformity to the Chaledonian resolutions; a possible factor in the waning cooperation between Byzantine and Ethiopia (Bowersock 2013:121; Phillipson 2012:204).

The combined Ethiopian-Byzantine forces converged at Gabaza, proceeded to Najran and there conquered Yusuf (Gajda 2009:108). Archaeological evidence attests to this episode and consequent erection of Churches at Sanaa (Lewcock 1979; Serjeant \& Lewcock 1983). The lack of overt cooperative policy between the two empires is attributed to the divergent doctrine of Ethiopia. Either way the client Christianity in Himyar was restored under a new client king Sumyafa Ashwa (Phillipson 2012:205).

Sumyafa Ashwa's reign was short lived as there was a Himyarite contender, Abraha, who deposed him in the late 530s, implying that Ethiopia's hold upon the client Christianity was rather fluid (Phillipson 2012:205). The cooperation between the two empires also waned as evident in the no show by the Ethiopians in the Persian-Byzantine war and the absence of Ethiopian influence in Himyar with the demise of Abraha (Bowersock 2013:122).

The rise of Islam, another unanticipated dynamic, was then definitive to the Christian polity of Ethiopia.

\section{Conclusion}

The early African Christian narrative was dominated by Alexandria and Carthage. There were definitive ecclesiastical polities that were consequent of controversies and correspondent councils. The post-Nicene polities and the Donatist-Catholic divide shaped events in Early African Christianity and also formed a political ideology. Departing from the prominent Augustine, an acculturated Roman aristocrat-turned-cleric, was a Christian political ideology of cooperation with the establishment. This is controverted by Donatus, who was a more extreme expression of Tertullian and Cyprian. The well-established ecclesiastical polity characterised by conciliar culture would intrinsically resemble an autonomous entity within the empire.

Drawing from ethnic and native sympathy, defined by charisma, the Donatist movement ideologised a Christian 
politic of resistance. Alexandria's Athanasius was also a juxtaposition of conformity and resistance to the imperial orthodoxy establishment. This background defined the Ethiopian Christian polity. The independence of Ethiopia from Byzantine military occupation because of its location in East Africa had implications on orthodoxy.

Ethiopia had a complex religious-political matrix as defined by the monastic establishments and its connections to Alexandria. The possibility that monastic orders were central catalysts to entrenchment of Christianity with natives shows Ethiopian Christianity as a synergy of charisma and ecclesiastical imperial political power. The ability of Athanasius to blend ascetism and the episcopal establishment was paralleled in Ethiopic ascetic-clerical links.

The confluence with Judaic Arabia coupled with the influence of the Syrian monks, who were Jewish Christians, serves to define Ethiopian Christianity, as separate entity from the 4thcentury Christendom. The interaction with the Byzantine emperor and the Monophysite-Miaphysite reaction by Ethiopia implies a complex religious-politic one of give-andtake. The complexity and singular characteristics of Ethiopian Christianity further establishes the need for a parallel investigation between Ethiopian Christianity and Byzantine imperial orthodoxy.

Ethiopia's synergy of asceticism and clerical hierarchies implied an effective native enculturation of Christianity. This added in the accretion of trajectory for a native orthodoxy. The Ethiopian native orthodoxy establishment was characterised by resistance against foreign elements and dually a capacity to co-exist with other religions and alternative confessions. The notable co-existence of Oromo Muslims and Christians during latter eras is evidence (Hassen 2015). The resistance to Islamic invasion and the catholic Jesuits was a continuum of the Christian polity that had developed in the early dispensation of Ethiopian Christianity (Jonas 2011).

The capacity to co-exist and resist was possibly a function of the distinctness that defined Ethiopian Christianity and its protection by the Negus. The preceding observation furthers the case for an investigation into Ethiopian Christianity and its influence, especially regarding its Africanised Christian politic.

\section{Acknowledgements}

The authors acknowledge the University of South Africa's research support for the preparation of this article.

\section{Competing interests}

The authors declare that they have no financial or personal relationships that may have inappropriately influenced them in writing this article.

\section{Disclaimer}

The views and opinions expressed in this article are those of the authors and do not necessarily reflect the official policy or position of any affiliated agency of the authors.

\section{Authors' contributions}

R.R. and E.O. equally contributed to this work. R.R. is the main author. E.O. is the co-author and was responsible for the guidance and consolidation of the process.

\section{References}

Amidon, P.R., 1997, The Church History of Rufinus of Aquileia, books 10 \& 11, Oxford University Press, New York.

Atkins, E.M. \&Dorado, R.J. (eds.), 2001, Augustine political writings, Cambridge University Press, New York.

Barnes, T.D., 2011, Constantine. Dynasty, religion and power in the late Roman Empire, Wiley-Blackwell, Chichester.

Behr, J., 2004, The Nicene Faith: Formation of Christian Theology, vol. 2, St Vladimir's Seminary Press, Crestwood.

Bowersock, G.W., 2013, The throne of Adulis: Red Sea Wars on the Eve of Islam, Oxford University Press, New York.

Brent, A., 2009, A Political History of Early Christianity, T \& T Clark, New York.

Brown, P., 2000, Augustine of Hippo: A Biography, University of California Press, Berkeley.

Budge, E.A.W., 1976, The Book of the Saints of the Ethiopian Church, 4 vols, Georg Olms Verlag Hildesheim, New York.

Dewing, H.B. (ed. \& trans.), 1914-1928, Procopius: History of the Wars, Heinemann (Loeb Classical Library), London.

Edwards, M., 2006, 'The beginnings of Christianization', in Lenski, N. (ed.), The Cambridge Companion to the Age of Constantine, pp. 137-158, Cambridge University Press, New York.

Eno, R.B. (trans.), 1997, Selected works (The Fathers of the Church). Fulgentius, Saint Fulgentius Bishop of Ruspa, CUA Press, Washington, DC.

Friedlander, M. \& Friedlander, B., 2015, Hidden treasures of Ethiopia: A guide to the remote churches of an ancient land, I.B. TAURIS, London.

Gajda, I., 2009, Le royaume de Himyar a l'epoque monotheiste, de Boccard (Memoires de I Academie des Inscriptions et Belles-Lettres 40), AIBL \& De Boccard, Paris.

Gwynn, D.M., 2012, Athanasius of Alexandria: Bishop, Theologian, Ascetic, Father, Oxford University Press, UK.

Hassen, M., 2015, The Oromo and the Christian Kingdom of Ethiopia 1300-1700, James Currey, New York.

Isaac, E., 2013, The Ethiopian Orthodox Tawahido Church, The Red Sea Press, Trenton, NJ.

Jonas, R., 2011, The Battle of Adwa: African victory in the age of empire, Harvard University Press, Cambridge, MA.

Kee, A., 2017, Constantine versus Christ: The triumph of Ideology, Wipf \& Stock, Eugene, OR.

Leithart, P.J., 2010, Defending Constantine: The twilight of an Empire and the Dawn of Christendom, InterVarsity Press, Downers Grove, IL.

Lewcock, R., 1979, 'La cathe'drale de Sanaa, foyer de christianisme en Arabie au vie siècle', Les Dossiers de l'Arche'ologie 33, 80-83.

Maier, P.L. (trans.), 2007, Eusebius, The Church History, Kregel Publications, Grand Rapids, MI.

Moorhead, J. (trans.), 1992, Victor of vita: History of the Vandal Persecution, vol. 11, Liverpool University Press translated texts for Historians, Liverpool University Press, Liverpool.

Pankhurst, R., 2005, Historic images of Ethiopia, Shama Books, Addis Ababa.

Phillips, V., 1917, The work of St. Optatus against the Donatists, Oxford University Press, New York.

Phillipson, D.W., 2012, Foundations of an African Civilisation: Aksum \& the Northern Horn 1000BC-AD 1300, James Currey, New York.

Rapp, C., 2005, Holy Bishops in late antiquity: The nature of Christian leadership in an age of transition, University of California Press, CA.

Roldanus, J., 2006, The church in the age of Constantine: The theological challenges, Routledge, New York.

Schaff, P. (ed.), 1885a, Ante-Nicene fathers, vol. 5: The Fathers of the Third Century: Hippolytus; Cyprian; Caius; Novatian; Appendix, Christian Classics Ethereal Library, Grand Rapids, MI.

Schaff, P. (ed.), 1885b, Nicene and Post-Nicene Fathers. Series 2. Vol. 1: Eusebius Pamphilius: Church history, life of Constantine, Oration in Praise of Constantine, Christian Classics Ethereal Library, Grand Rapids, MI. 
Schaff, P. (ed.), 1885c, Nicene and Post-Nicene Fathers. Series 2. Vol. 3: Theodoret, Jerome, Gennadius, \& Rufinus: Historical Writings, Christian Classics Ethereal Jerome, Gennadius, \&
Library, Grand Rapids, Ml.

Schaff, P. (ed.), 1885d, Nicene and Post-Nicene Fathers. Series 2. Vol. 4: Athanasius: Select works and letters, Christian Classics Ethereal Library, Grand Rapids, MI.

Schaff, P. (ed.), 1885e, Nicene and Post-Nicene Fathers. Series 2. Vol. 11:Sulpitius Severus, Vincent of Lerins, John Cassian, Christian Classics Ethereal Library, Grand Rapids, MI.

Serjeant, R.B. \& Lewcock, R. (eds.), 1983, San'a: An Arabian Islamic city, World of Islam Festival Trust, London.
Tilley, M.A., 2012, 'North Africa', in M.M. Mitchell \& F.M. Young (eds.), The Cambridge History of Christianity: Origins to Constantine, pp. 485-503, Cambridge University Press, New York.

Van Dam, R., 2012, 'Bishops and society', in A. Casiday \& F.W. Norris (eds.), The Cambridge History of Christianity: Constantine to c. 600, pp. 343-367, Cambridge University Press, New York.

Whelan, R., 2018, Being Christian in Vandal Africa: the politics of orthodoxy in the Post-Imperial West, University of California Press, Oakland, CA.

Wilhite, D.E., 2017, Ancient African Christianity: An introduction to a unique context and tradition, Routledge, New York. 